\title{
ACKNOWLEDGEMENTS
}

I would like to thank the Austrian Academy of Sciences (AAS), the Presiding Committee, the Section for the Humanities and the Social Sciences and its full member o. Univ.-Prof. Dr. Hans-Dieter Klein for making possible the $3^{\text {rd }}$ International Symposium Psychoanalysis as an Empirical, Interdisciplinary Science, dedicated to both Continental and Anglo-American research, at the Festival Hall of the Austrian Academy of Sciences in Vienna from November 22 to 24, 2002.

Chapter 1, "Approaching Contemporary Psychoanalytic Research", is an updated and modified version of the following two presentations: my lecture "Understanding Freud's Approach to the Mind through the Philosophy of Mind - Understanding Current Topics of the Philosophy of Mind through Psychoanalysis", given on July 23, 2001 at the $42^{\text {nd }}$ International Psychoanalytical Association (IPA) Congress in Nice and my paper "First-Person Perspective and Third-Person Perspective in Clinical and Empirical Psychoanalytic Research", delivered on November 22, 2002 at the above mentioned $3^{\text {rd }}$ International Symposium Psychoanalysis as an Empirical, Interdisciplinary Science.

Chapters 2, 4, 5, 6, 7, 8, 9, 10, 11 and 12 first originated in shorter form in the papers held at the $3^{\text {rd }}$ International Symposium Psychoanalysis as an Empirical, Interdisciplinary Science.

Chapter 3, "Drive Theory and Primary Process: A Philosophical Account", was written for the present volume after this meeting.

I would like to thank my research assistant Mag. Alexander Hippmann, as well as my assistants Stefan Fock and Robert Göschl for revising the bibliography. Robert Göschl also provided the layout of the manuscript.

As always, I am grateful as well to my patients, students, candidates and colleagues, especially to the colleagues of the College of Research Fellows of the International Psychoanalytical Association (IPA) for their constant support.

Most of all I would like to thank my husband Johannes and my son Italo-Léon for their encouragement and patience. I am much in their debt for so many years of love.

Vienna

October 2004 


\section{BIBLIOGRAPHICAL NOTE OF THE EDITOR}

In this volume the publications of Sigmund Freud are quoted from:

Freud, S. S.E. The Standard Edition of the Complete Psychological Works of Sigmund Freud. 24 Volumes, trans. and ed. J. Strachey in collaboration with A. Freud, A. Strachey, A. Tyson \& A. Richards. London: The Hogarth Press 1953-1974.

The chronological order of his writings is based upon the bibliography:

Meyer-Palmedo, I. \& Fichtner, G., ed. (1989). FreudBibliographie mit Werkkonkordanz. (Freud-Bibliography and Concordance of His Publications). Frankfurt am Main: Fischer, pp. 15-90.

In addition to the notes of the authors, supplementary notes of the editor appear in angular parentheses and are headed by the remark [Note of the editor:]. Angular parentheses are also applied for quoting references not taken into account (omitted) by the authors. 
Introduction 
